\title{
PENGARUH PARTISIPASI ANGGOTA, IKLIM ORGANISASI, TERHADAP KEPUASAN ANGGOTA YANG DIMEDIASI KINERJA PENGURUS SEBAGAI VARIABEL INTERVENING PADA KOPERASI DWIPANTI KOTA SALATIGA TAHUN 2018
}

\author{
Oleh : \\ Samtono \\ Dosen Tetap STIEPARI Semarang
}

\begin{abstract}
Abstrak
Tujuan penelitian ini untuk menganalisi dan menjelaskan Pengaruh Partisipasi Anggota, dan Iklim Organisasi terhadap Kinerja Pengurus, serta Bagaimana Kinerja Pengurus memediasi Partisipasi Anggota dan Iklim Organisasi terhadap Kepuasan Anggota koperasi Dwipanti.

Metode penelitian menggunakan pendekatan kuantitatif jenis eksplanatori, Populasi sebesar 1.120 orang anggota koperasi, Penentuan sampel dengan teknik Slovin dan terpilih menjadi sampel sebesar 120 orang. Pengambilan sampel dengan cara acak atau sembarang Pengambilan data dengan teknik kuesioner dan observasi..

Hasil analisa data diperolah hasil : Pertama, Tidak Ada pengaruh positif dan siqnifikan Partisipasi Anggota terhadap Kinerja Pengurus koperasi, dan Kedua, ada pengaruh positif dan siqnifikan Iklim Organisasi terhadap Kinerja Pengurus koperasi, Ketiga, Kinerja Pengurus juga berpengaruh secara positif dan siqnifikan terhadap Kepuasan Anggota koperasi Selanjutnya Kempat, Kinerja Pengurus secara positif dan siqnifikan memediasi Partisipasi Anggota terhadap Kepuasan Anggota koperasi, dan Kelima, Kinerja Pengurus secara positif dan siqnifikan tidak memediasi Iklim Organisasi terhadap Kepuasan Anggota koperasi Dwipanti Kota Salatiga.
\end{abstract}

Kata Kunci : partisipasi anggota, iklim organisas, kinerja pengurus, dan kepuasan anggota.

\section{PENDAHULUAN}

Peran dan fungsi dari koperasi Dwipanti Salatiga selama ini sangat membantu para anggotanya, sebagian besar anggotanya para guru-guru SD yang sudah Pegawai Negeri Sipil ( PNS ) dilingkungan pemerintahan Kota Salatiga. Koperasi Dwipanti didirikan sejak 15 Januari 1976, dan sudah memiliki ijin yang berbadan hukum dengan Nomor: 8910/1976 dari Departemen Koperasi, dan sampai sekarang jumlah anggotanya mencapai 1120 orang. Pengurus bertanggung jawab segala kegiatan pengelolaan koperasi dan usahanya yang dipertanggungjawabkan kepada rapat anggota. Adapun tugas-tugas pengurus koperasi sesuai dengan UU RI Nomor 25 
Tahun 1992 pasal 30 sebagai berikut : 1.Mengelola koperasi dan usahanya, 2.Mengajukan Rancangan Program Kerja serta Rencana Pendapatan dan Belanja Koperasi (RAPBK), 3.Menyelenggarakan Rapat Anggota, 4.Mengajukan Laporan Keuangan dan Pertanggungjawaban Pelaksanaan Tugas, 5.Menyelenggarakan perubahan keuangan dan inventaris secara tertib, 6.Memelihara daftar buku anggota (materi diklat koperasi, 2007: 7 ). Atas dasar keenam tugas pengurus koperasi tersebut akan diteliti sejauh mana kinerja pengurus koperasi menjalankan tugas dan fungsiya serta bagaimana peran sebagai mediator dalam kepengurusan koperasi. Berkaitan dengan hal tersebut akan diteliti tentang Partisipasi Anggota, Iklim Organisasi, terhadap Kepuasan Anggota Koperasi Dwipanti, dan Kinerja Pengurus sebagai Variabel Intervening. Penegasan Menteri Pembangunan Daerah Tertinggal Republik Indonesia, dalam sambutannya pada peluncuran buku "Nyala Obor di Kala Hujan, Koperasi Indonesia, Rumah Kita", pada tahun 2010, menyatakan , "Pembudayaan koperasi dan usaha mikro, kecil, dan menengah (UMKM) merupakan salah satu upaya strategi dalam meningkatkan taraf hidup sebagian besar rakyat Indonesia, berdasarkan Rencana Pembangunan Jangka Panjang Nasional 2005-2025 (RPJPN). Pemberdayaan koperasi dan UMKM dipilah menjadi pengembangan usaha kecil dan menengah (UKM), pemberdayaan usaha mikro, dan penguatan kelembagaan koperasi. Usaha untuk pemberdayaan koperasi salah satunya adalah dalam rangka untuk mempercepat penurunan tingkat kemiskinan sesuai harapan pemerintah (Bachrudin, 2010:7)

\section{RUMUSAN MASALAH}

Berdasarkan uraian diatas, maka masalah yang peneliti kemukakan adalah :

1. Bagaimanakah pengaruh partisipasi anggota terhadap kinerja pengurus koperasi Dwipanti Salatiga?

2. Bagaimana pengaruh Iklim organisasi terhadap kinerja pengurus Dwipanti Kota Salatiga?

3. Bagaimanakah pengaruh kinerja pengurus Dwipanti Salatiga terhadap kepuasan anggota koperasi Dwipanti Kota Salatiga?

4. Apakah kinerja pengurus koperasi memediasi partisipasi anggota terhadap kepuasan anggota koperasi Dwipanti Kota Salatiga? 
5. Apakah kinerja pengurus koperasi Dwipanti memediasi iklim kerja terhadap kepuasan kerja anggota koperasi Dwipanti Kota Salatiga ?

\section{TUJUAN PENELITIAN}

1. Untuk menganalisis dan menjelaskan pengaruh pertisipasi anggota terhadap kinerja pengurus koperasi dwipanti Kota salatiga

2. Untuk menganalisis dan menjelaskan pengaruh iklim organisasi terhadap kinerja pengurus koperasi Dwipanti Kota Salatiga

3. Untuk menganalisis dan menjelaskan pengaruh kinerja pengurus terhadap kepuasan anggota koperasi Dwipanti Kota Salatiga

4. Untuk menganalisis dan menjelaskan, apakah kinerja pengurus memedisi partisipasi anggota terhadap kepuasan anggota koperasi Dwipanti Kota Salatiga

5. Untuk menganalisis dan menjelaskan, apakah kinerja pengurus koperasi memediasi iklim organisasi terhadap kepuasan anggota koperasi Dwipanti Kota Salatiga.

\section{PAPARAN TEORITIS}

\section{a. Partisipasi Anggota}

Partisipasi adalah turut sertanya seseorang baik secara mental atau emosional untuk memberikan sumbangsih kepada proses pembuatan keputusan, terutama mengenai persoalan - persoalan dimana keterlibatan pribadi orang yang bersangkutan melaksanakan tanggung jawabnya untuk melakukan hal tersebut (Bachrudin 2010:142). Dari pendapat tersebut dapat disimpulkan partisipasi, adalah keikutsertaan anggota dalam kegiatan koperasi serta kesediaan anggota untuk memikul kewajiban dan menjalankan hak keanggotaan secara bertanggung jawab. Partisipasi anggota koperasi menurut statusnya dapat diperinci (Rusidi dalam Bachrudin,2010:127), menjadi : (a). Partisipasi anggota dalam rapat anggota tahunan (sebagai pemilik). (b). Partisipasi anggota dalam penanaman modal melalui berbagai macam simpanan, (c).Partrisipasi anggota sangat menentukan maju mundurnya sebuah koperasi yang ditandai dengan dari waktu kewaktu bertambahnya modal usaha koperasi. Adapun akumulasi modal koperasi, antara lain : 1)Skala usaha koperasi lebih besar sehingga lebih ekonomis. 2).Cara 
produksi koperasi lebih maju. 3).Volume usaha koperasi meningkat. 4).Tingkat pertumbuhan koperasi makin cepat, dan seterusnya. Koperasi harus benar-benar mampu mewujudkan kepentingan bersama para anggotanya dan tujuan itu dicapai berdasarkan sumbangan atau dukungan para anggota yang tercermin dalam karya dan jasa masing-masing (E.Vigeleyn dalam Materi Diklat Koperasi,2007:26).

\section{b. Kinerja Pengurus}

Kinerja atau prestasi kerja adalah hasil kerja secara kualitas dan kuantitas yang dicapai oleh seseorang pegawai dalam melaksanakan tugasnya sesuai dengan tanggung jawab yang diberikan kepadanya. ( Mangkunegara,2004:67). Selanjutnya Sulistiyani (2003:223) "Kinerja seseorang merupakan kombinasi dari kemampuan, usaha dan kesempatan yang dapat dinilai dari hasil kerjanya. Ruky $(2002 ; 14)$ kinerja atau sering disebut dengan prestasi sebenarnya merupakan pengalih bahasaan dari Bahasa Inggris dari kata "performance". Lebih lanjut kata performance dapat diartikan sebagai berikut : 1).Prestasi yang digunakan dalam konteks atau kalimat misalnya tentang mobil yang sangat cepat (high performance car). 2).Pertunjukkkan yang biasanya digunakan dalam kalimat "Folk Dance Performance". 3.)Pelaksanaan tugas misalnya dalam kalimat "In performing his/her duties".

Kinerja tidak lepas dari manajemen kinerja, yang mana pada dasarnya manajemen kinerja adalah sebuah proses dalam manajemen tersebut mempunyai implikasi bahwa kegiatan tersebut harus dilaksanakan sebagai sebuah proses manajemen yang umum yang dimulai dengan penetapan tujuan dan sasaran, dan diakhiri dengan evaluasi (Materi Diklat Koperasi,2007:26). Dari beberapa penjelasan tersebut diatas akhirnya dapat diambil garis besarnya, agar pengurus koperasi mempunyai kinerja yang baik, seseorang harus mempunyai keinginan yang tinggi untuk mengerjakan serta mengetahui pekerjaannya. Tanpa mengetahui jenis dan tanggung jawab pekerjaannya maka kinerja yang baik tidak akan pernah tercapai.

\section{c. Iklim Organisasi}

Menurut Sutarto dalam Materi diklat koperasi (2007:36) organisasi adalah sistem saling pengaruh antar orang dalam kelompok yang bekerja sama untuk mencapai tujuan tertentu. Berdasarkan definisi ini dapat diketemukan adanya 
berbagai faktor yang dapat menimbulkan organisasi, yaitu orang-orang, kerjasama dan tujuan tertentu. Berbagai faktor tersebut tidak dapat saling lepas berdiri sendiri, melainkan saling kait mengait dan merupakan suatu kebulatan. Selanjutnya Wheelen \& Hunger dalam Hanggraeni ( 2011:151) mengatakan iklim organisasi dekat dengan kultur organisasi yang dapat diartikan sebagai nilai-nilai yang dianut bersama oleh anggota organisasi dan diwariskan dari satu generasi kegenerasi berikutnya, sedangkan menurut Burhanudin (2010:252) Iklim organisasi didefinisikan sebagai perangkat ciri internal yang membedakan satu lembaga koperasi dari yang lain dan mempengaruhi tingkah laku manusia. Jadi dapat dikatakan bahwa iklim lembaga atau organisasi koperasi adalah kondisi lembaga koperasi yang diwujudkan berdasarkan seperangkat nilai atau norma, kebiasaan, dan ditopang sarana prasarana yang tersedia.

\section{d. Kepuasan anggota}

Kepuasan secara ruang lingkup sempit dapat diartikan sebagai upaya pemenuhan sesuatu, Kolter dalam Materi diklat koperasi (2007: 117) menyebutkan kepuasan adalah perasaan senang atau kecewa seseorang yang berasal dari perbandingan antara kesannya terhadap kinerja ( hasil ) sesuatu produk dengan harapannya. Selanjutanya Tjiptono ( 2000: 182 ) mengatakan kepuasan adalah semacam langkah perbandingan antara pengalaman dengan hasil evaluasi, dapat menghasilkan sesuatu yang nyaman secara rohani, bukan hanya nyaman karena dibayangkan atau diharapkan. Puas atau tidak puas bukan merupakan emosi tetapi merupakan hasil evaluasi dari emosi. Beberapa indikator untuk memberikan kepuasan anggota koperasi manakala terjadi ada perubahan dan kemajuan dalam pengelolaan sehingga terjadi perkembangan dan perubahan keadaan menjadi lebih baik dan nampak progresnya (Bachrudin, 2010:157). Koperasi adalah usaha bersama (Yulius , 1998:14). Jadi perkembangan koperasi berarti perubahan keadaan usaha koperasi menjadi lebih besar. Dapat kita terima dan kita amati, bahwa pertumbuhan koperasi selalu berarti adanya akumulasi koperasi baik dalam sumber daya produksi modal maupun akumulasi dalam sumber daya manusia. 


\section{KERANGKA PEMIKIRAN}

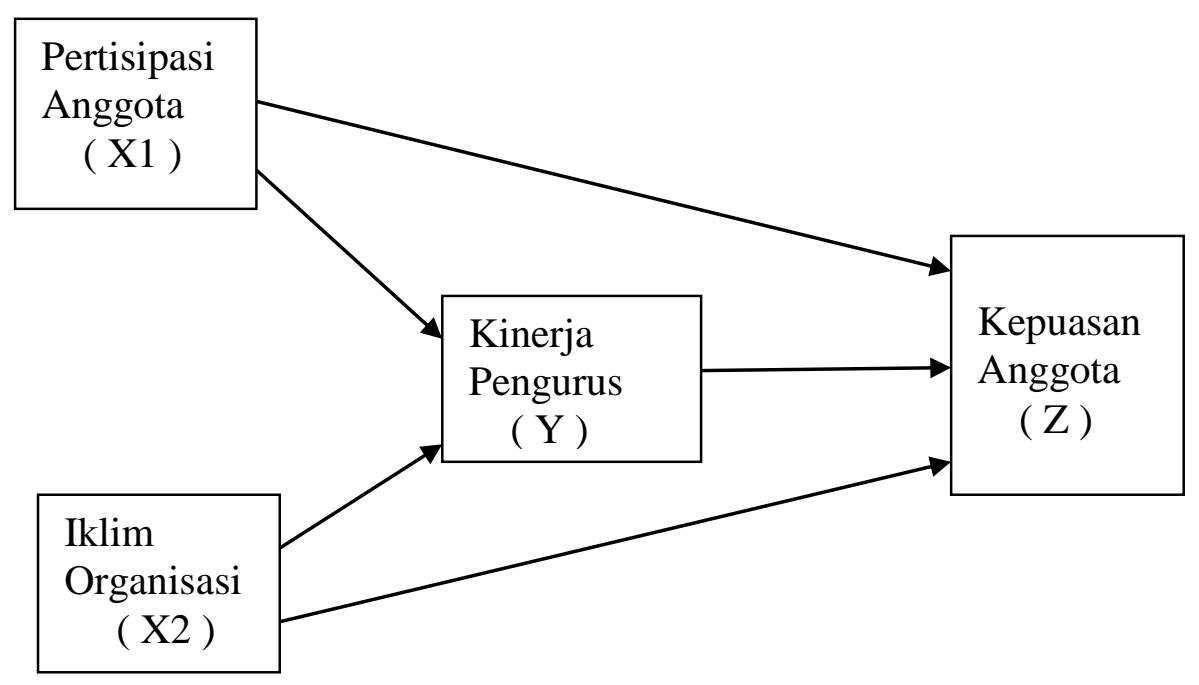

\section{METODE PENELITIAN}

Dalam penelitian ini menggunakan pendekatan Kuatitatif tipe/jenis eksplanatoris artinya untuk mengetahui pengaruh antar variabel baik secara parsial maupun secara bersama-sama atau stimulan, dengan tujuan untuk menjelaskan pengaruh antara dua atau lebih gejala atau variabel yaitu pengaruh variabel bebas partisipasi anggota dan iklim organisasi terhadap variabel terikat kepuasan anggota melalui variabel intervening ( kinerja pengurus koperasi dwipanti Salatiga ).

\section{Populasi dan sampel}

Populasi adalah wilayah generalisasi yang terdiri atas obyek/subyek yang mempunyai kuantitas dan karakteristik tertentu yang diterapkan oleh peneliti untuk dipelajari dan kemudian ditarik kesimpulannya. (Sugiyono , 2014:81) Adapun yang menjadi subyek dalam penelitian disini adalah semuanggota koperasi dwipanti kota Salatiga sebanyak 1120 orang kecuali pengurus koperasi dwipanti sebanyak 7 orang. Adapun sampel yang diambil dalam penelitian ini adalah sebesar 10\% dari jumlah populasi sebanyak 1120 orang anggota Koperasi Dwipanti, adapun penentuan sampel berdasarkan teknik Slovin dan pengambilannya dengan teknik acak, sehingga didapatkan sampel sebesar 120 orang. 


\section{Definisi Operasional}

Definisi operasional adalah suatu definisi yang diberikan kepada suatu variabel atau konstruk dengan cara memberikan arti atau menspesifikasikan kegiatan atau memberikan operasional yang diperlukan untuk mengukur konstruk (Sugiyono, 2006 : 58). Definisi operasional dalam penelitian ini sebagai berikut :

1) Partisipasi Anggota (X1) diukur dari dimensi:

(a).Permodalan; (b).Rapat-rapat anggota; (c).Jasa pelayanan terhadap anggota; (d).Kemajuan usaha anggota; (e).Partisipasi

2) Iklim Organisasi (X2, diukur dari dimensi : (a).Ketepatan struktur organisasi; (b).Ketepatan visi, misi serta tugas pokok; (c).Tingkat tanggungjawab pegawai; (d).Tingkat Kepedulian pimpinan; (e).Kelengkapan sarana dan prasarana

3) Kinerja Pengurus (Y), diukur dari dimensi : (a).Mengelola Usaha; (b)Membuat RAPBK; (c).Menyelenggarakan rapat anggota; (d).Laporan pertanggung jawaban; (e).Menyelenggarakan perubahan

4) Kepuasan Anggota (Z), diukur dari dimensi : (a) Kualitas produk; (b) Kualitas Layanan; (c) Faktor Emosional; (d) Harga lebih rendah dari yang lain; (e) Biaya dan kemudahan mendapatkan produk

\section{METODE ANALISIS DATA}

Metode analisis kuantitatif adalah suatu teknik analisis data yang sudah diolah dalam bentuk angka-angka dan pembahasannya melalui perhitungan statistik. Tahap analisis data yang dipergunakan dalam penulisan ini dapat dijelaskan sebagai berikut :

\section{a. Tahap pengolahan data}

Tahap pengolahan data meliputi : Coding; Scoring atau pemberian nilai dengan menggunakan skala Likert; dan Tabulasi atau pengelompokkan jawaban kuesioner.

\section{b. Tahap analisis data}

Tahap analisis data dimulai dengan : 


\section{a) Uji Validitas}

Uji Validitas yang digunakan dalam penelitian ini adalah validitas internal dengan menggunakan analisis faktor yaitu dengan cara mengkorelasikan skor faktor dengan rumus Product Moment dari Carl Pearson

\section{b) Uji Reliabilitas}

Pada penelitian ini untuk mencari reliabilitas instrumen menggunakan rumus alpha, karena berbentuk kuesioner yang skornya merupakan rentangan antara 1-5. maka menggunakan rumus Alpha .

\section{c) Analisis Persamaan Regresi Berganda Model 1}

Untuk mengetahui pengaruh partisipasi anggota, kinerja pengurus dan iklim organisasi terhadap perkembangan Koperasi digunakan model Analisis Regresi Linier, dari Sugiyono (2006;36) digunakan untuk mengetahui besarnya pengaruh atribut-atribut $\mathrm{X}_{1}, \mathrm{X}_{2}$, terhadap $\mathrm{Y}$, dengan rumus :

$$
\mathrm{Y}=\mathrm{b}_{1} \cdot \mathrm{X}_{1}+\mathrm{b}_{2} \cdot \mathrm{X}_{2}
$$

$$
\begin{aligned}
& \text { Keterangan : } \mathrm{X}_{1} \text { : Partisipasi Anggota } \\
& \mathrm{X}_{2} \text { : Iklim Organisasi } \\
& \text { Y : Kinerja Pengurus } \\
& \text { b : Standardized Coefficients }
\end{aligned}
$$

d) Analisis Persamaan Regresi Berganda Model 2, dengan Rumus:

$$
\begin{aligned}
& \mathrm{Z}: \mathrm{b}_{1} \cdot \mathrm{X}_{1}+\mathrm{b}_{2} \cdot \mathrm{X}_{2}+\mathrm{b} . \mathrm{Y} \\
& \text { Keterangan }: \mathrm{X}_{1}: \text { Variabel Partisipasi Anggota } \\
& \mathrm{X}_{2}: \text { Variabel Iklim Organisasi } \\
& \mathrm{Y}: \text { Variabel Kinerja Pengurus } \\
& \mathrm{Z}: \text { Variabel Kepuasan Anggota } \\
& \mathrm{b}: \text { Standardized Coefficients }
\end{aligned}
$$

e) Uji Model

\section{(1) Uji F (Anova)}

Uji F digunakan untuk mengetahui pengaruh secara simultan atau bersama-sama variabel indevenden terhadap variabel devenden dengan rumus sebagai berikut : 
F hitung =

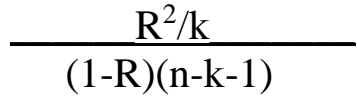

Keterangan $: R^{2}=$ Kowfisien Determinasi

$\mathrm{K}=$ Jumlah Variabel bebas

$\mathrm{N}$ = Jumlah Sampel dengan tingkat kepercayaan $95 \%$ atau

Tingkat taraf siqnifikan 5\%

a. Jika F Hitung < F Tabel, maka variabel indevenden tidak berpengaruh terhadap variabel devenden

b. Jika F Hitung > F Tabel, maka variabel indevenden mempunyai pengaruh terhadap variabel devenden

\section{(2) Uji Koefisien Determinasi (Uji $\mathbf{R}^{2}$ )}

Koefisien determinasi (Adjust $R$ Square) digunakan untuk mengetahui seberapa besar prosentase yang mampu dijelaskan oleh variabel partisipasi anggota, dan iklim organisasi terhadap kepuasan anggota dengan kinerja pengurus sebagai variabel intervening atau mediasi pada koperasi wipanti Kota Salatiga

\section{f) Uji t (t-Test)}

Uji t digunakan pengujian hipotesis penelitian. Adapun penjelasannya adalah sebagai berikut:

Ho diterima : $\mathrm{t}$ table $<\mathrm{t}$ hitung

Ho ditolak : $\mathrm{t}$ table $>\mathrm{t}$ hitung atau $-\mathrm{t}$ table $<\mathrm{t}$ hitung

Dalam memudahkan penghitungan analisis data, maka penulis menggunakan alat bantu analisis data melalui komputerisasi dengan menggunakan program SPSS 11 for windows.

\section{g) Uji Mediasi}

Mediasi merupakan variabel antara yang berfungsi memediasi hubungan antara variabel indevenden dengan variabel devenden. Untuk menguji pengaruh variabel variabel mediasi digunakan metode analisis jalur (path analysis).Dengan analisis jalur dapat menentukan pola hubungan tiga atau lebih variabel dan tidak dapat digunakan untuk mengkonfirmasi atau menolak hipotesis kausalitas (Ghozali,2005:246) 
PENYAJIAN DATA DAN ANALISA DATA

Tabel 1

Hasil Analisis Regresi Linier Berganda 1

Coefficients $^{2}$

\begin{tabular}{|l|c|r|r|r|r|}
\hline \multirow{2}{*}{ Model } & \multicolumn{2}{|l|}{$\begin{array}{l}\text { Unstandardized } \\
\text { Coefficients }\end{array}$} & $\begin{array}{l}\text { Standardized } \\
\text { Coefficients }\end{array}$ & \multirow{2}{*}{ Siq } \\
\cline { 2 - 5 } & B & Std Error & \multicolumn{1}{|c|}{ Beta } & & \\
\hline (Contant ) & 1.718 & 8.033 & & .214 &, 831 \\
X1 Partisipasi & -.022 & .109 & -.016 & -.197 &, 844 \\
$\begin{array}{l}\text { Anggota } \\
\text { X2 Iklim }\end{array}$ & 1.845 & .211 & .706 & 8.760 &, 000 \\
Organisasi & & & & & \\
\hline
\end{tabular}

a.Dependent Variable : Y Kinerja Pengurus

Sumber: Data primer yang sudah diolah 2018,

Standardized Coefficents pada persamaan diatas digunakan untuk mengetahui besarnya kontribusi masing-masing faktor yang mempengaruhi terhadap kinerja pengurus, yaitu variabel iklim organisasi karena memiliki nilai Standardized Coefficients sebesar 0.706, lebih besar dibandingkan dengan nilai Standardized Coefficients partisipasi anggota sebesar 0.016

Tabel 2

Hasil Analisis Regresi Linier Berganda 2 Coefficients $^{2}$

\begin{tabular}{|c|c|c|c|c|c|}
\hline \multirow[t]{2}{*}{ Model } & \multicolumn{2}{|c|}{$\begin{array}{l}\text { Unstandardized } \\
\text { Coefficients }\end{array}$} & \multirow{2}{*}{\begin{tabular}{|c}
$\begin{array}{l}\text { Standardized } \\
\text { Coefficients }\end{array}$ \\
Beta
\end{tabular}} & \multirow[t]{2}{*}{$\mathrm{t}$} & \multirow[t]{2}{*}{ Siq } \\
\hline & B & Std Error & & & \\
\hline (Contant) & 10.584 & 2.650 & & 3.994 & .000 \\
\hline X1 Partisipasi & -.032 & .036 & -.053 & -.878 & ,382 \\
\hline Anggota & & & & & \\
\hline X2 Iklim & .596 & .097 & .517 & 6.166 &, 000 \\
\hline Organisasi & & & & & \\
\hline $\begin{array}{l}\text { Y Kinerja } \\
\text { Pengurus }\end{array}$ & .170 & .036 & .387 & 4.677 & .000 \\
\hline
\end{tabular}

a.Dependent Variable : $\mathrm{Z}$ Kepuasan Anggota

Sumber : Data pimer yang sudah diolah 2018

Standardized Coefficients pada persamaan diatas digunakan untuk mengetahui besarnya kontribusi masing-masing faktor yang mempengaruhi terhadap kepuasan anggota, dari persamaan tersebut faktor yang paling berpengaruh/dominan terhadap 
kepuasan anggota adalah iklim organisasi karena memiliki nilai Standardized Coefficients lebih besar yaitu 0.517 , diikuti kinerja pengurus 0.387 , dan partisipasi anggota dengan nilai -0.053

\section{Uji F (Anova)}

Uji $\mathrm{F}$ dilakukan untuk mengetahui signifikan hubungan antara variabel $\mathrm{X}_{1}, \mathrm{X}_{2}$ dan $\mathrm{X}_{3}$ apakah benar-benar berpengaruh secara bersama-sama (simultan) terhadap variabel Y. Hasil pengolahan data dikethaui bahwa nilai F-hitung sebagaimana tersebut pada Tabel 4.13 berikut ini.

Tabel 3

Hasil Uji F (Anova) ${ }^{a)}$ Model 1

\begin{tabular}{|l|c|c|c|c|c|}
\hline \multicolumn{1}{|c|}{ Model } & $\begin{array}{c}\text { Sum of } \\
\text { Squares }\end{array}$ & df & $\begin{array}{c}\text { Mean } \\
\text { Square }\end{array}$ & F & Siq \\
\hline Regression & 3638.520 & 2 & 1819.260 & 41.630 & $.000^{\mathrm{b}}$ \\
Residual & 3583.480 & 82 & 43.701 & & \\
Total & 7222.000 & 84 & & & \\
\hline
\end{tabular}

Devendent Variable : Kinerja Pengurus (Y)

Predictors (Constant), Partisipasi Anggota, Iklim Organisasi

Sumber : Data primer yang sudah diolah, 2018

Tabel diatas menunjukkan hasil uji $\mathrm{F}$ hitung yaitu $14.630>\mathrm{F}$ table 3 dengan probabilitas 0.000 dibawah 5\%. Hal ini berarti variabel indevenden untuk model 1 secara bersama-sama berpengaruh terhadap variabel dependen.

Tabel 4

Hasil Uji F (Anova $\left.{ }^{a}\right)$ Model 2

\begin{tabular}{|l|c|c|c|c|c|}
\hline \multicolumn{1}{|c|}{ Model } & $\begin{array}{c}\text { Sum of } \\
\text { Squares }\end{array}$ & Df & $\begin{array}{c}\text { Mean } \\
\text { Square }\end{array}$ & F & Siq \\
\hline Regression & 1017.211 & 3 & 339.070 & 71.367 & $.000^{\mathrm{b}}$ \\
Residual & 384.836 & 81 & 4.751 & & \\
Total & 1402.047 & 84 & & & \\
& & & & & \\
\hline
\end{tabular}

Devendent Variable : Kepuasan Anggota (Z)

Predictors (Constant), Partisipasi Anggota, Iklim Organisasi, Kinerja Pengurus Sumber : Data primer yang sudah diolah, 2018

Tabel 4 diatas menunjukkan hasil uji $\mathrm{F}$ hitung yaitu $71.367>\mathrm{F}$ tabel 3.11 dengan probabilitas 0.000 dibawah 5\%. Hal ini berarti variabel indeveden untuk model 2 secara bersama-sama berpengaruh terhadap variabel dependen. 


\section{Uji Koefisien Determinasi}

Koefisien determinasi menurut sugiyono (2004) adalah untuk mengukur secara terpisah dampak variabel independent $\mathrm{X}_{1}, \mathrm{X}_{2}$, dan $\mathrm{X}_{3}$ yaitu partisipasi anggota, kinerja pengurus dan iklim organisasi terhadap variabel dependent $Y$ yaitu perkembangan koperasi. Dari hasil pengolahan data dengan menggunakan program SPSS for Windows, diperoleh hasil sebagaimana Tabel 5 berikut ini :

Tabel 5

Hasil Uji Analisis Koefisien Determinasi Model 1

\begin{tabular}{|c|c|c|c|c|}
\hline Model & R & R Square & $\begin{array}{c}\text { Adjusted R } \\
\text { Square }\end{array}$ & $\begin{array}{c}\text { Std Error of the } \\
\text { Estimate }\end{array}$ \\
\hline 1 & $.710^{\mathrm{a}}$ & .504 & .492 & 6.611 \\
\hline
\end{tabular}

Predictors (Constant), Partisipasi Anggota, Iklim Organisasi

Sumber : Data primer yang sudah diolah, 2018

Berdasarkan tabel 5 model 1, menunjukkan bahwa Adjusted R Square 49.2\% artinya variabel indevenden untuk model ini yaitu Partisipasi Anggota dan Iklim Organisasi mempengaruhi Kinerja Pengurus sebasar $49.2 \%$, sedang sisanya $40.8 \%$ dijelaskan variabel lain yang tidak dimasukan dalam model ini (yang tidak diteliti)

Tabel 6

Hasil Uji Analisis Koefisien Determinasi Model 2

\begin{tabular}{|c|c|c|c|c|}
\hline Model & $\mathrm{R}$ & R Square & $\begin{array}{c}\text { Adjusted R } \\
\text { Square }\end{array}$ & $\begin{array}{c}\text { Std Error of the } \\
\text { Estimate }\end{array}$ \\
\hline 1 & $.852^{\mathrm{a}}$ & .726 & .715 & 2.180 \\
\hline
\end{tabular}

Predictors (Constant), Partisipasi Anggota, Iklim Organisasi, Kinerja Pengurus, Sumber : Data primer yang sudah diolah, 2018

Berdasarkan tabel 6 model 2, menunjukkan bahwa Adjusted $R$ Square $71.5 \%$ artinya variabel indevenden untuk odel ini yaitu partisipasi anggota, iklim organisasi, kinerja pengurus, mempengaruhi kepuasan anggota sebesar $71.5 \%$, sedangkan sisanya $28.5 \%$ dijelaskan variabel lain yang tidak masuk dalam penelitian disini (tidak diteliti). 


\section{Uji Hipotesis}

\section{a. Uji t (Parsial)}

\section{Hipotesis pertama :}

Ada pengaruh positif dan siqnifikan, partisipasi anggota terhadap kinerja pengurus koperasi Dwipanti Kota Salatiga. Hasil uji analisis regresi linear berganda model 1 tabel 1, menunjukkan bahwa nilai siqnifikansi untuk variabel partisipasi anggota 0.844 lebih besar dari nilai probabilitas 0.05 dan nilai t hitung adalah -.197 lebih kecil dari nilai t table 1.989. Maka variabel partisipasi anggota tidak berpengaruh positif dan siqnifikan terhadap kinerja pengurus koperasi Dwipanti Kota Salatiga. Artinya hipotesis pertama ditolak.

\section{Hipotesis kedua:}

Ada pengaruh positif dan siqnifikan, iklim organisasi terhadap kinerja pengurus Dwipanti Kota Salatiga. Hasil uji analisis regressi menunjukan bahwa nilai siqnifikansi variabel iklim organisasi 0.000 lebih kecil dari nilai probabilitas 0.05 dan nilai t hitung 8.760 lebih besar dari nilai t table 1.989, maka variabel iklim organisasi berpengaruh positif dan siqnifikan terhadap kinerja pengurus koperasi Dwipanti Kota Salatiga. Artinya hipotesis kedua diterima.

\section{Hipotesis ketiga:}

Ada pengaruh positif dan siqnifikan variabel kinerja pengurus terhadap kepuasan anggota koperasi Dwipanti Kota Salatiga. Hasil uji analisis regresi pada tabel 2 menunjukan bahwa nilai siqnifikansi variabel kinerja pengurus 0.000 lebih kecil dari nilai probabilitas 0.05 dan nilai t hitungnya adalah 4.677 lebih besar dari nilai t table 1.989, maka variabel kinerja pengurus koperasi berpengaruh secara positif dan siqnifikan terhadap kepuasan anggota koperasi Dwipanti Kota Salatiga. Artinya hipotesis ketiga diterima.

\section{Hipotesis keempat:}

Ada pengaruh positif dan siqnfikan kinerja pengurus memediasi partisipasi anggota terhadap kepuasan anggota koperasi Dwipanti Kota Salatiga 


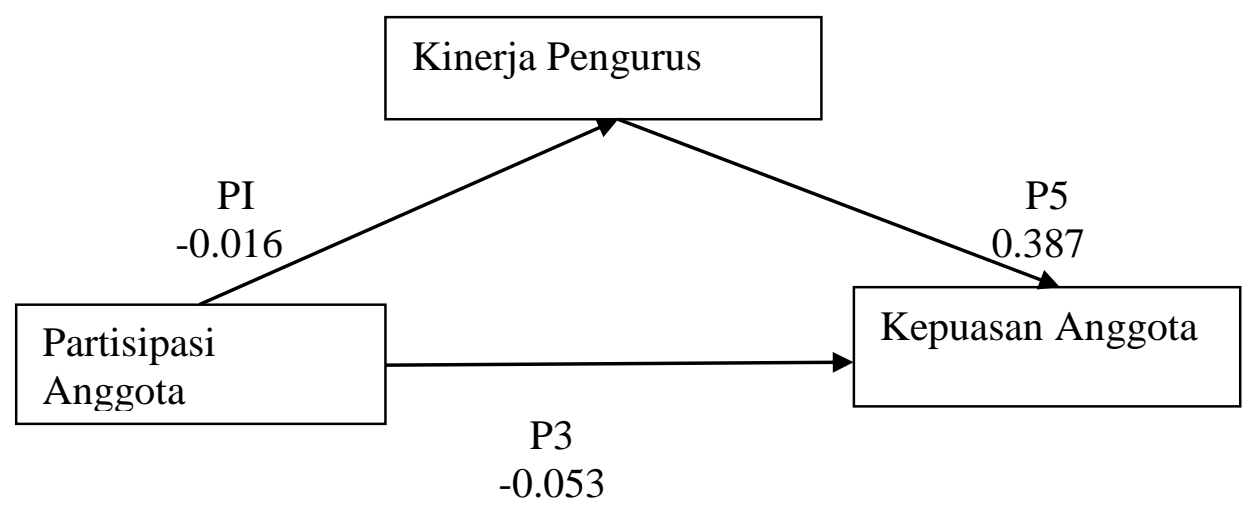

Pengujian dilakukan menggunakan analisis jalur (path analysis) dengan berdasarkan pada nilai Standardized Coefficients Beta pada gabungan tabel 1 dan tabel 2 dengan perhitungan sebagai berikut:

Partisipasi anggota X1 $\rightarrow$ Kinerja pengurus Y $(\mathrm{PI})=-0.016$

Partisipasi anggota X1 $\longrightarrow$ Kepuasan anggota Z $($ P3 $)=-0.053$

Kinerja pengurus $\mathrm{Y} \longrightarrow$ Kepuasan anggota $\mathrm{Z}(\mathrm{P} 5)=0.387$

Nilai perhitungan langsung $(\mathrm{P} 3)=-0.053$

Nilai perhitungan tidak langsung $($ P1 x P5 $)=-0.016 \times 0.387=-0.006$

Hasil perhitungan diatas diketahui, nilai perhitungan tidak langsung yaitu $-0.006>$ dari nilai perhitungan langsung yaitu -0.053. shingga dapat disimpulkan bahwa ada pengaruh positif dan siqnifikan kinerja pengurus memediasi partisipasi anggota terhadap kepuasan anggota koperasi Dwipanti Kota Salatiga. Artinya hipotesis keempat diterima.

\section{Hipotesis kelima:}

Ada pengaruh positif dan siqnifikan kinerja pengurus memdiasi iklim organisasi terhadap kepuasan anggota operasi Dwipanti Kota Salatiga

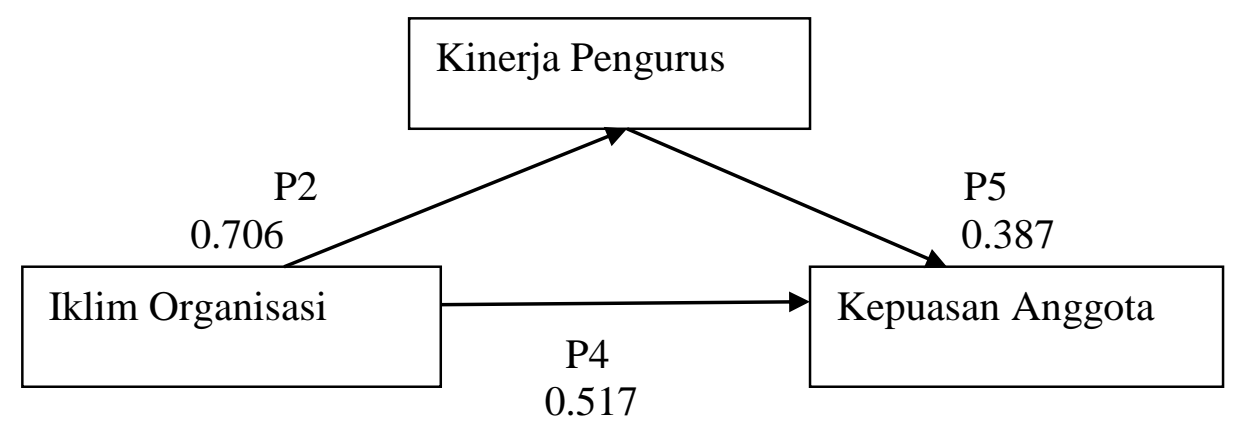


Pengujian dilakukan menggunakan analisis jalur (path analysis) dengan berdasarkan pada nilai Standardized Coefficients Beta pada gabungan table 4.11 dan table 4.12, dengan perhitungan sebagai berikut :

Iklim organisasi X2 $\rightarrow$ Kinerja pengurus $\mathrm{Y}(\mathrm{P} 2)=0.706$

Iklim organisasi X2 $\rightarrow$ Kepuasan anggota Z $(\mathrm{P} 4)=0.517$

Kinerja pengurus $\mathrm{Y} \rightarrow$ Kepuasan anggota $\mathrm{Z}(\mathrm{P} 5)=0.387$

Nilai perhitungan langsung $(\mathrm{P} 4)=0.517$

Nilai prhitungan tidak langsung $(\mathrm{P} 2 \times \mathrm{P} 5)=0.706 \times 0.387=0.273$

Hasil nilai perhitungan diatas diketahui : nilai perhitungan tidak langsung yaitu 0.273 $<$ dari nilai perhitungan langsung 0.517 , sehingga dapat disimpulkan bahwa tidak ada pengaruh positif dan siqnifikan kinerja pengurus tidak memediasi variabel iklim organisasi terhadap variabel kepuasan anggota kopeasi Dwipanti Kota Salatiga. Artinya hipotesis kelima tidak diterima/ditolak.

\section{SIMPULAN DAN SARAN}

\section{Kesimpulan}

1. Bahwa partisipasi anggota tidak mempengaruhi kinerja pengurus koperasi Dwipanti Kota Salatiga, artinya manakala pengurus kurang atau tidak mengakomodir aspirasi atau masukan-masukan anggotanya dengan sendirinya sangat berpengaruh terhadap kinerja pengurus, selanjutnya pengurus harus lebih terbuka dan komunikatif dalam menyampaikan program-program untuk kemajuan dan perkembangan koperasi kedepan sehigga para anggota bisa memahami dan mengerti secara jelas hak dan kewajiban sebagai seorang anggota koperasi.

2. Iklim organisasi berpengaruh terhadap kinerja pengurus Dwipanti Kota Salatiga. Diantaranya adalah pemahaman, pengetahuan, dan kemampuan, para anggota didalam menjadi anggota komunitas organisasi di koperasi Dwipanti sangat memahami dan menyadari akan eksistensi atau keberadaan pengurus beserta tugas pokok dan fungsi dalam suatu organisasi pada koperasi.

3. Kinerja pengurus berpengaruh terhadap kepuasan anggota koperasi Dwipanti Kota Salatiga. Diantaranya adalah struktur organisasi yang tepat dan sesuai dengan visi dan misi, tingkat tanggungjawab dan kepedulian pengurus 
terhadap kepentingan anggota serta kelengkapan sarana dan prasarana koperasi, guna menunjang kemajuan koperasi dimasa depan.

4. Kinerja pengurus memediasi partisipasi anggota terhadap kepuasan anggota koperasi Dwpanti Kota Salatiga. Artinya manakala anggota koperasi berpartisipasi secara aktif pada organisasi koperasi serta komunikatif terhadap pengurus maka dengan sendirinya pengurus akan memberikan pelayanan terhadap anggotanya semaksimal mungkin demi memberikan pelayanan yang prima supaya kepuasan para anggota koperasi dapat terpenuhi.

5. Kinerja pengurus tidak memediasi iklim organisasi terhadap kepuasan anggota koperasi. Artinya manakala kondisi atau iklim organisasi koperasi kuang kondusif dan kurang harmonis antara pengurus dengan budaya organisasi yang ada , maka dengan sendirinya akan terjadi kendala antara misi organisasi terhadap apa yang menjadi harapan dan keinginan para anggota, dan pengurus senantiasa untuk selalu menjalankan roda organisasi sebaik mungkin dan transparan serta jujur dan penuh tanggung jawab.

\section{Saran}

1. Beberapa variabel yang sudah terbukti ada pengaruh secara positif dan siqnifikan antara variabel indevenden terhadap variabel devenden perlu ditingkatkan agar perjalanan organisasi koperasi punya masa depan yang lebih jelas dan berkelanjutan.

2. Variabel Partisipasi anggota tidak berpengaruh terhadap variabel kinerja pengurus koperasi, dipandang perlu pengurus lebih aktif, komunikatif, dan kooperatif didalam mensosialisasikan tentang hak dan kewajiban para anggota koperasi agar lebih jelas, paham, dan mengerti apa yang menjadi tanggung jawanya, serta tidak kalah pentingnya pengurus harus bisa menjelaskan terhadap para anggota tentang tugas pokok dan fungsi pengurus koperasi

3. Variabel kinerja pengurus tidak memediasi variabel iklim organisasi terhadap variabel kepuasan anggota, artinya perlu dikaji secara cermat dan menyeluruh dan terintegrasi, mengapa kinerja pengurus selama ini yang sudah bekerja secara maksimal belum menunjukan iklim organisasi yang dibangun belum memberikan kepuasan para anggotanya. Dipandang perlu adanya penelitian lebih lanjut guna mengungkap mengapa bisa terjadi seperti itu. 


\section{DAFTAR PUSTAKA}

Arikunto, Suharsini, 2002, Metodologi Penelitian, Rineka Cipta, Semarang

Dewi Hanggraeni, 2011, Perilaku Organisasi, Teori, Kasus, dan Analisis, Lemba Penerbit : Fakultas Ekonomi Universitas Indonesia, Jakarta

Entang A Sastra, 1984, Perkembangan Koperasi Teori dan Kenyataan, Bandung : PT. Angkasa.

Hadi, Sutrisno, 2000, Metodologi Research. Jilid 1, Yayasan Penerbitan UGM, Yogyakarta.

IHalauw, J.O.I, 2010, Bangunan Teori, Edisi Milenium, Fakultas Ekonomi UKSW, Salatiga.

Mangkunegara, Prabu, Anwar, 2004, Manajemen Sumber Daya Manusia Perusahaan, Penerbit Remaja Rosdakarya, Bandung.

Martoyo, Susilo, 2000, Manajemen Sumber Daya Manusia, Yogyakarta, BPFE Yogyakarta.

Ranupandojo, Heidjrachman, 2000, Manajemen Modern, Bagian Penerbitan Fakultas Ekonomi, Yogyakarta

Rucky, Achmad S, 2002, Sistem Manajemen Kinerja, Jakarta: Gramedia Pustaka

Simamora, H, 1997, Manajemen Sumber Daya Manusia, STIE YKPN, Yogyakarta.

Sugiyono, 2006, Statistik Untuk penelitian, Alfa Beta, Bandung.

, 2014, Metode penelitian Kuantitatif, Kualitatif dan $R \& D$, Alfa Beta, Bandung

Sugiarto, Endar,2002, Psikologi Pelayanan dalam Industri Jasa, Gramedia Pustaka Utama, Jakarta.

Umarni, Murti dan Salamah Wahyuni, 2006 Metodologi Penelitian Bisnis.

Tatang, Bachrudin Rachmad, 2010, Nyala Obor di Kala Hujan, Koperasi Indonesia, Rumah Kita, Yayasan Obor Nusantara, Jakarta.

Tjiptono,Fandi, 2000, Manajemen Jasa, Yogyakarta, Andi Offset

Usman, Husaini dan Purnomo Setiady Akbar, 2006, Pengamtar Statistika, Bumi Aksara, Jakarta. 
Wahjosumidjo, 2000, Teori Kepemimpinan dan Dasar-Dasar Manajemen, Lembaga Administrasi Negara, Jakarta.

Yuniarsih, Tjutju dan Suwatno, 2008, Manajemen Sumber Daya Manusia, Teori, Aplikasi dan Isu Penelitian, Alfabeta, Bandung.

-------------, 2000, Manajemen Personalia dan Sumber Daya Manusia , Yogyakarta, BPFE Yogyakarta

Materi Pelatihan, 2007 Diklat koperasi Guru, Kementrian Negara Koperasi dan Usaha Kecil dan Menengah Republik Indonesia, Jakarta.

Undang-Undang RI Nomor 25 tahun 1992, tentang Perkoperasian.

Keputusan Presiden RI Nomor 68 tahun 1998 tentang pembinaan kursus dan Lembaga Pelatihan Kerja.

http//www.wikipedia.Com, 2009 